\title{
How my failure to read a play helped my students develop their learning
}

\author{
Lucinda Becker \\ University of Reading
}

Keywords: student confidence; Shakespeare; Covid-19

\section{The challenge}

As a teaching-intensive member of academic staff, I have an active interest in how students can develop their learning skills, particularly in English Literature. The pandemic gave me an unexpected opportunity to address a key area of learning development that has always been a challenge amongst my students. In English Literature at my university, we teach through lectures and through seminars of around 15 students. These seminars are intended to give space to students trying out new ideas and closely analysing literature. However, too often they are spaces in which many students are silent, passive learners. This is nothing to do with the intelligence of the students, but arises from a missing piece of learning development related to the challenge faced by my students during the pandemic: how to prepare for a seminar.

This sounds simple, but for most students it is not. Prior to university they are not expected to read a whole new play each week, as we do on the Shakespeare module (course) I convene. In their anxiety to get to grips with material quickly, they often go to secondary sources (television, films or study guides) and are flummoxed in the seminar when they are expected to have read the whole play. This can lead to students preferring the comfort of silence to the challenge of responding to questions or discussion points offered by the seminar leader; they feel underprepared and so find it safer to disengage rather than expose what they fear might be a lack of familiarity with the primary text. 


\section{The response}

As the Shakespeare module was taught wholly online this year, I took the opportunity to bring together the whole module group (around 50 students in their second year of university) in weekly, online, recorded play readings. There were three student volunteers reading from the module in each session, taking it in turns to read the speeches, and each week we covered one play. Attendance at the sessions was voluntary, and they were set up online via Blackboard Collaborate. The benefit of using this method was that it appeared in students' timetables and was a familiar online learning activity space for them. It also allowed me to record the sessions and embed them in a Blackboard module easily and swiftly.

My aim was to achieve three learning development goals:

1. To ensure that students had read the play before the relevant seminar.

2. To help them feel more confident in seminars, as they would know the play.

3. To create an informal, enjoyable learning community throughout lockdown.

I think we achieved these goals, with students giving positive feedback on this aspect of the module. The learning community was even better than I had expected; around a quarter of the students had performed in or directed Shakespeare plays, and so brought that perspective to the group. This gave us the chance to recognise their previous learning development and feed that into their new learning.

The learning community was diverse in geographical origin, and I was at first surprised to find that three students whose first language was not English were keen to take a turn reading the plays. When I complimented their reading after one session, they told me that they had decided to read aloud in the group because the Shakespearean language is challenging and so brings with it a sense of trepidation but also satisfaction once it is 'conquered' (as they put it).

For those students with an auditory (aural) learning preference, this was clearly going to be an especially beneficial experience, and I shared the text on screen to aid visual learners; I noticed that some of the readers were walking around as they read the text, showing a kinaesthetic preference, perhaps. Kolb's work over nearly four decades, 
developing the idea of learning styles and the importance of experiential learning, learning by doing, sets up a framework within which this type of activity sits well (Kolb, 2015).

I also learned two things about myself. As we read the plays together, I noticed elements in the plays that I had never spotted before. By being open and sharing this with students they could recognise that the learning was genuinely shared - I was leading, but that did not mean that I was not learning beside them.

I also found that I am not very good at reading plays aloud. In fact, I am fairly disastrous at it. I tend to rush through familiar speeches, and I speak too fast anyway. Having assumed that I would always be leading, I then recognised that the students were better readers than I was, and I turned the reading over to them entirely. This made a significant change in our relationship. They were developing learning skills, such as gaining an ear for the language and immersing themselves in a text, in a situation in which they had largely taken over the learning space - I was the assistant who scrolled through the play text onscreen. The students recognised that they were investing more effort than they were used to, as they were taking the lead, and this energised the group. They seemed more ready to proffer their views in our seminars following the play readings, and this reflects Tinto's assertion that 'the more students invest in learning activities [. . .] the higher their level of effort, the more students learn' (Tinto, 1997, p.600).

Once the term was over, I adopted Brookfield's method to reflect on whether this learning experiment had any value beyond the pandemic (Brookfield, 2009). My Shakespeare students no longer have to bluff their way through a text, so I can be bolder in my learning expectations; their learning confidence has also increased because of this experiment. Kahu's work recognises that 'satisfaction' and 'wellbeing' are two social factors that promote student engagement and learning, and online reading groups can achieve this - it is the act of sharing a text that seemed to make the difference to these students (Kahu, 2013).

\section{Recommendations}

I no longer think it matters too much what we are reading online. It is the experience of being together online whilst all sitting in the safe spaces of our homes that fostered the 
bravery it must have taken for those students to read a play to their fellow students. This is an innovation that I plan to keep. I will be running online play reading sessions even when we are back on campus. This is partly a practical decision (I want to record the readings, and this is much easier to do through an online session) and partly a personal/pedagogical choice (I know that this works online and am hesitant about taking it offline given the benefits it brings to the students).

The gains in terms of making a semi-social learning space online have encouraged me to go further. I intend to read sections of novels and pieces of poetry with students next year, and we will do this online rather than on campus. I am reminded again of the research carried out by Tinto, which was some time ago, yet his assertion that 'the classroom is the crossroads where the social and the academic meet' (Tinto, 1997, p.599) is still relevant. The fact that this classroom is non-traditional and online worked to our advantage.

From my observations, my inability to read those plays successfully was a milestone in my relationship with this group of students. We could all recognise that I was not the only expert in the room, and I could see their confidence grow, along with their openness to trying new approaches to the texts in our seminars, which in turn developed their learning skills. Whilst I am not, of course, advocating teacher failure as a go-to way to develop learning, I am pleased that, in this case at least, it was part of the key to success.

\section{References}

Brookfield, S. (2009) 'The concept of critical reflection: promises and contradictions', European Journal of Social Work, 12(3), pp.293-304. Available at: https://doi.org/10.1080/13691450902945215 (Accessed: 5 October 2021).

Kahu, E.R. (2013) 'Framing student engagement in higher education', Studies in Higher Education, 38(5), pp.758-773. Available at: https://www.tandfonline.com/doi/pdf/10.1080/03075079.2011.598505 (Accessed: 5 October 2021).

Kolb, D.A. (2015) Experiential learning: experience as the source of learning and development. $2^{\text {nd }}$ edn. Upper Saddle River, New Jersey: Pearson Education, Inc. 
Tinto, V. (1997) 'Classrooms as communities: exploring the educational character of student persistence', The Journal of Higher Education, 68(6), pp.599-623. Available at: https://doi.org/10.2307/2959965 (Accessed: 5 October 2021).

\section{Author details}

Lucinda Becker is Professor of Pedagogy in the Department of English Literature at the University of Reading. 